\title{
Adrenocortical carcinoma: presentation and outcome of a contemporary patient series
}

\author{
liro Kostiainen ${ }^{1} \cdot$ Liisa Hakaste ${ }^{1} \cdot$ Pekka Kejo $^{2} \cdot$ Helka Parviainen $^{3} \cdot$ Tiina Laine $^{4} \cdot$ Eliisa Löyttyniemi ${ }^{5}$.

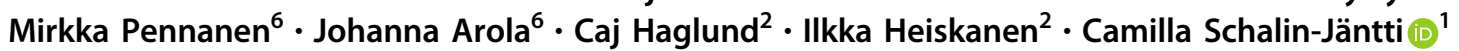

Received: 5 February 2019 / Accepted: 28 March 2019 / Published online: 12 April 2019

(C) The Author(s) 2019

\begin{abstract}
Background Adrenocortical carcinoma (ACC) is a rare endocrine carcinoma with poor 5-year survival rates of $<40 \%$. According to the literature, ACC is rarely an incidental imaging finding. However, presentation, treatment and outcome may differ in modern series.

Design and methods We studied all patients ( $n=47$, four children) from a single centre during years 2002-2018. We reevaluated radiologic and histopathological findings and assessed treatments and outcome. We searched for possible TP53 gene defects and assessed nationwide incidence of ACC.

Results In adults, incidental radiologic finding led to diagnosis in $79 \%$ at median age of 61 years. ENSAT stage I, II, III and IV was $19 \%, 40 \%, 19 \%$ and $21 \%$, respectively. Nonenhanced CT demonstrated $>20$ Hounsfield Units (HU) for all tumours (median 34 (21-45)), median size $92 \mathrm{~mm}$ (20-196), Ki67 17\% (1-40\%), Weiss score 7 (4-9) and Helsinki score 24 (4-48). ACC was more often found in the left than the right adrenal $(p<0.05)$. One child had Beckwith-Wiedemann and one a TP53 mutation. In adults, the primary tumour was resected in 88 and $79 \%$ received adjuvant mitotane therapy. Median hospital stay was significantly shorter in the laparoscopic vs. open surgery group (4 (3-7) vs. 8 (5-38) days, respectively; $p<0.001)$. In $3 / 4$ patients, prolonged remission of $>5$ to $>10$ years was achieved after repeated surgery of metastases. Overall 5-year survival was $67 \%$, and $96 \%$ vs. $26 \%$ for ENSAT stage I-II vs. III-IV $(p<0.0001)$. ENSAT stage and Ki67 predicted survival, type of surgery did not. Mitotane associated with better survival.

Conclusions Contemporary ACC predominantly presents as an incidental imaging finding, characterised by $\mathrm{HU}>20$ on nonenhanced CT but variable tumour size $(20-196 \mathrm{~mm})$. Malignancy cannot be ruled out by small tumour size only. The 5year survival of $96 \%$ in ENSAT stage I-III compares favourably to previous studies.
\end{abstract}

Keywords Adrenocortical carcinoma $\cdot$ ENSAT stage $\cdot$ Hounsfield units $\cdot$ Mitotane $\cdot$ Surgery $\cdot$ Complications $\cdot$ Survival

Camilla Schalin-Jäntti

camilla.schalin-jantti@hus.fi

1 Endocrinology, Abdominal Center, Helsinki University Hospital and University of Helsinki, Helsinki, Finland

2 Department of Surgery, Helsinki University Hospital and University of Helsinki, Helsinki, Finland

3 HUS Medical Imaging Centre, Radiology, Helsinki University Hospital and University of Helsinki, Helsinki, Finland

4 Children's Hospital, Helsinki University Hospital and University of Helsinki, Helsinki, Finland

5 Department of Biostatistics, University of Turku and Turku University Hospital, Turku, Finland

6 Department of Pathology, University of Helsinki and HUSLAB, Helsinki, Finland

\section{Introduction}

Adrenocortical carcinoma (ACC) is a rare and aggressive endocrine malignancy that can occur at any age. In adults, the estimated incidence of ACC is one per million per year $[1,2]$. Most series report 5-year survivals $<40 \%$ [1, 3-11]. In children $<3$ years, 5-year disease-free survival after total resection is $80 \%$, while in those $>13$ years survival is $40 \%$, similar to that in adults $[2,12]$. Disease stage, best defined by the European Network for the Study of Adrenal Tumours (ENSAT stage), radical surgery, age, Ki67 and Helsinki Score seem to predict survival [2, 3, 13-15]. Adjuvant mitotane is recommended in adult patients with high risk of recurrence $[16,17]$ and mitotane monotherapy or combined mitotane and etoposide-doxorubicin cisplatin treatment for advanced disease [18, 19]. 
Previously, $10-15 \%$ of ACCs have presented as incidental imaging findings [20, 21], while reported prevalence of ACC among adrenal incidentalomas has varied between $1-11 \%$ [22]. However, incidentally discovered asymptomatic adrenal masses are getting more common due to increasing use of imaging [22, 23]. We hypothesised that presentation and outcome of ACC may differ in modern compared to old series. We here report data on presentation, treatment and outcome in a contemporary series, including all patients from a single centre diagnosed in 2002 to 2018, and nationwide incidence of ACC in 2001-2015.

\section{Subjects and methods}

\section{Patient population}

Patients were identified from the Helsinki University Hospital pathology registry and electronic patient records using ICD-10 codes C74.0 and 74.9. All cases (Weiss score $\geq 4$ [24, 25]) diagnosed between 1 January 2002 and 27 April 2018 were included.

\section{Histopathological evaluation}

Two endocrine pathologists (M.P., J.A.) re-evaluated all tumours and determined Ki67, Weiss and Helsinki scores [13]. One tumour with Weiss score 3 was excluded.

\section{Radiologic evaluation}

Preoperative computed tomography (CT) images were reevaluated with the Agfa Impax PACS software by an abdominal radiology specialist (H.P.). Tumour size was defined as largest axial plane diameter. Presence or absence of tumour thrombus or distant metastases was evaluated from contrast-enhanced images. Hounsfield units (HU) were measured from noncontrast images by placing a single round region of interest (ROI) on the tumour. The ROI covered the largest possible part of the tumour plane, avoiding necrosis, haemorrhage and calcifications.

\section{Data collection}

Data on clinical presentation, laboratory measurements, tumour characteristics, surgery, histopathology and adjuvant treatments during years 2002 to 2018 were collected from our electronic patient records. All laboratory tests, including germline gene mutation testing, were performed with in house methods in the Helsinki University Hospital Central Laboratory, HUSLAB. We used ENSAT Criteria (stage $\mathrm{I}=$ tumour diameter $\leq 5 \mathrm{~cm}$, stage II tumour diameter
$>5 \mathrm{~cm}$, stage III = infiltration of neighbouring structures, venous tumour thrombosis in caval or renal vein, or positive lymph nodes, stage IV $=$ distant metastases) [3]. We registered recurrences and deaths. We retrieved nationwide number of ACC cases and age standardised 5-year incidences from the Finnish Cancer Registry; www.ca ncersociety.fi.

The study protocol was approved by the board review of the Abdominal Centre, Helsinki University Hospital.

\section{Statistical analysis}

Data is presented as median (interquartile range, IQR, or range) for continuous variables. For categorical data, rates and proportions were calculated. Fisher exact test was used for calculation of differences between groups. Mean ranks between groups were compared with Mann-Whitney- $U$-test. Median survival was calculated according to Kaplan-Meier and predictors of survival with Cox proportional hazards regression analyses. All reported $p$-values are two-sided. $p$ values $<0.05$ (two-tailed) were considered statistically significant. Ki-67 was grouped in three categories: (1) 1-9\%, (2) $10-19 \%$ and $(3) \geq 20 \%$. Calculations were performed with SPSS25.

\section{Results}

\section{Patient characteristics}

Altogether 47 patients, 4 (9\%) being children, were diagnosed with ACC. In adults, median age at diagnosis was 61 years (IQR 53-66), 25 (58\%) were female and median follow-up was 35 months (IQR 8-89). At presentation, 15/ $42(36 \%)$ had non-specific abdominal pain and 6/42 (14\%) bruises; 5/25 (24\%) women had hirsutism and the youngest woman (20 years) menstrual disturbances. Eight patients had potassium concentrations $<3.5 \mathrm{mmol} / 1$ ( $<3.0 \mathrm{mmol} / \mathrm{l}$ in 7, lowest $1.6 \mathrm{mmol} / \mathrm{l}$ ). Sixty-three percent had biochemically verified adrenal hormone excess. Isolated hypercortisolism $(41 \%)$ was most common, followed by excess cosecretion of cortisol and androgens (22\%), isolated hyperandrogenism (19\%), co-secretion of aldosterone and cortisol and aldosterone (11\%) and isolated aldosterone excess $(7 \%)$.

\section{Characteristics of children with adrenocortical carcinoma}

Characteristics of children with ACC are given in Table 1. Patients 3 and 4 presented with clinical signs of hyperandrogenism, and patient 1 with signs of hypercortisolism. 
Table 1 Characteristics of paediatric patients $(n=4)$ with ACC

\begin{tabular}{|c|c|c|c|c|}
\hline & Patient \#1 & Patient \#2 & Patient \#3 & Patient \#4 \\
\hline Age (years) & 0.3 & 1.3 & 1.6 & 5.2 \\
\hline Sex & Male & Female & Female & Male \\
\hline Symptoms and signs & $\begin{array}{l}\text { Developmental delay, hypertension, } \\
\text { increased weight, decreased length } \\
\text { growth velocity, left ventricle } \\
\text { hypertrophy }\end{array}$ & None & $\begin{array}{l}\text { Pubic hair, } \\
\text { clitoromegaly }\end{array}$ & $\begin{array}{l}\text { Pubic hair, penile growth, increase } \\
\text { in height, deepening of voice, } \\
\text { advanced bone age of } 12.8 \text { years }\end{array}$ \\
\hline $\begin{array}{l}\text { Biochemically } \\
\text { verified } \\
\text { hormone excess }\end{array}$ & Hypercortisolism & None & Hyperandrogenism & Hyperandrogenism \\
\hline Tumour size (mm) & 59 & 24 & 57 & 33 \\
\hline Location & Right adrenal & Right adrenal & Right adrenal & Left adrenal \\
\hline Weiss score & 5 & 7 & 6 & 6 \\
\hline ENSAT stage & II & I & II & I \\
\hline Genetics & $\begin{array}{l}\text { Hypomethylation of } K C N Q 1 O T \text { gene } \\
\text { (Beckwith-Wiedemann syndrome) }\end{array}$ & $\begin{array}{l}\text { Germline TP53 } \\
\text { mutation (Li- } \\
\text { Fraumeni } \\
\text { syndrome) }\end{array}$ & None & None \\
\hline
\end{tabular}

Figure 1 demonstrates typical growth charts in hyperandrogenism (patient 4; Fig. 1a) and hypercortisolism (patient 1, Fig. 1b). Patient 2 was asymptomatic with normal biochemistry, and diagnosed with an adrenal tumour when undergoing abdominal ultrasound screening because of familial Li-Fraumeni syndrome (Table 1).

Time between diagnosis and surgery was 7, 8 and 16 days in symptomatic patients and 51 days for the nonsymptomatic child. Three children were discharged on the fourth postoperative day, postoperative recovery of patient 1 included 2 days in ICU, 49 days in the paediatric ward and chemotherapy on the 52nd postoperative day. All children received 4-6 cycles of adjuvant etoposidecisplatin therapy. At 7.9 years (1.5-11.8 years) of followup, all children are in remission and have reached the developmental milestones according to age. So far, children with Beckwith-Wiedemann and Li-Fraumeni syndrome have not displayed other manifestations. Patient 4 predictably developed precocious central puberty and received GnRH-analogue therapy from 6.2 to 13.8 years of age (Fig. 1a). After cessation of GnRH-therapy, puberty proceeded normally and he reached his adult target height.

\section{TP53 and other gene defects and cancers in patients with adrenocortical carcinoma}

Gene defects in children are presented in Table 1. Ten adult patients (age $<20$ years $(n=3)$, concomitant other cancers (follicular lymphoma, earlier ACC and breast cancer, lung adenocarcinoma, prostate cancer $(n=4))$ or strong family history of cancer $(n=3))$ were screened for germline TP53 gene mutations, all were negative.

\section{Nationwide incidence of adrenocortical carcinoma during years 2006-2015}

The nationwide number of new cases was 32 during years 2006-2010, and 41 during 2011-2015, respectively. The corresponding 5-year age standardised incidence rates per one million person-years were 0.9 and 1.0 in years 2006-2010 and 2011-2015, respectively.

\section{Radiologic characteristics of adrenocortical carcinoma and ENSAT staging in adult patients}

Median tumour size was $91.5 \mathrm{~mm}$ (IQR 52.3-133.0) with no significant gender difference $(p=0.98)$ (Table 2). Thirty-one $(72 \%)$ tumours originated from the left and 12 (28\%) from the right adrenal $(p=0.046)$. Thirty-four $(79 \%)$ of the tumours were incidental imaging findings. Median tumour density (30/43 patients) was $33.5 \mathrm{HU}$ (IQR 28.5-38). HU was equally high in men and women (32.5, IQR 25.5-36.5 vs 34.0, IQR 29.4-39.5, respectively, $p=$ 0.31 ) On imaging, one patient had two tumour masses (both $\mathrm{HU}>21$ ) in the same adrenal.

At presentation, 8 patients $(19.0 \%)$ had stage I disease, $17(40.5 \%)$ stage II, $8(19.0 \%)$ stage III and $9(21.4 \%)$ stage IV (Table 2). There was no significant difference in the proportion of men and women in ENSAT groups I-II compared to III-IV $(p=1.0)$.

\section{Surgery in adult patients with adrenocortical carcinoma}

Surgical characteristics are given in Table 3. The primary tumour was operated in $38(88 \%)$ patients. One tumour was 
A

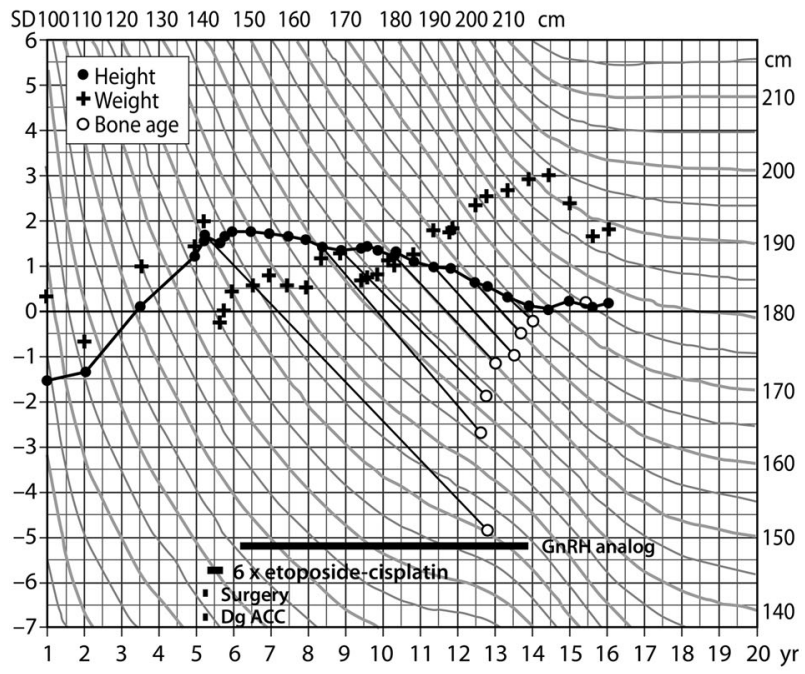

B

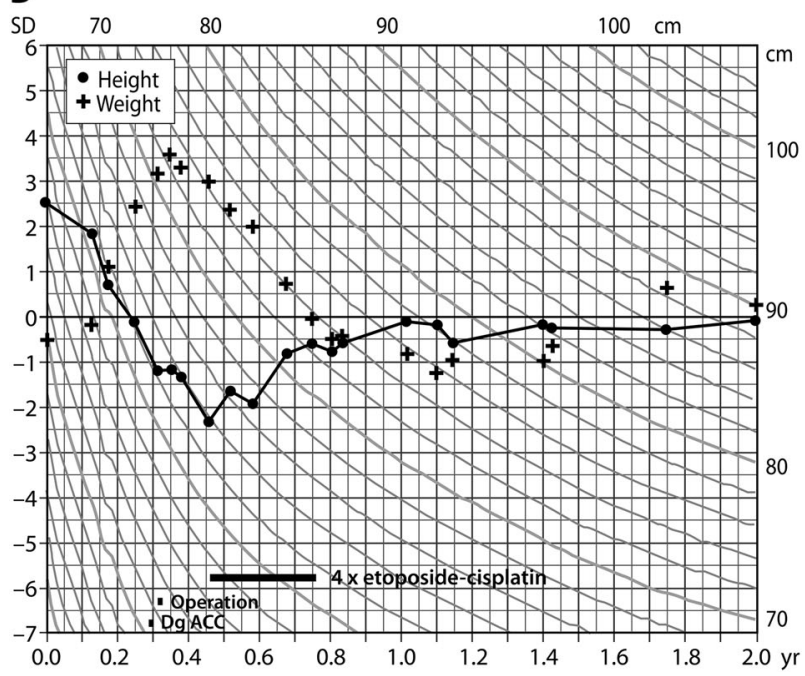

Fig. 1 a Growth chart demonstrates accelerated growth in a 5-year-old boy with androgen secreting ACC. Hyperandrogenism resulted in advanced bone age (12.8 years) and subsequent precocious central puberty that was treated with GnRH-analogue therapy from 6.2 to 13.8 years of age. b Growth chart of a 0.3-year-old boy with cortisol secreting ACC causing weight gain and decreased height velocity

removed after prolonged pre-treatment with mitotane. One patient was attempted to operate on twice, but was inoperable due to vascular tumour involvement. Four patients were not operated on (two with large metastatic tumour burden, two with significant surgical risks). Twenty surgeries were open adrenalectomies, 16 laparoscopic and 3 other laparoscopic surgeries were converted to open surgery (Table 3). The laparoscopic group included successful surgery of four tumours ranging from $60-100 \mathrm{~mm}$. Additional organs (eight kidneys, five spleens, three partial resections of pancreas, one partial liver resection) were resected in ten operations.
Table 2 Radiologic and histologic characteristics of the tumours

\begin{tabular}{lll}
\hline Variable & Median & Range \\
\hline Tumour size $(\mathrm{mm})^{\mathrm{a}}$ & 91.5 & $20-196$ \\
Radiopacity $(\mathrm{HU})^{\mathrm{a}}$ & 33.5 & $21-45$ \\
Ki67 (\%) & 17 & $1-40$ \\
Weiss score & 7 & $4-9$ \\
Helsinki score & 25 & $4-48$ \\
& $\mathrm{n}$ & $\%$ \\
ENSAT stage & & \\
I & 8 & 19 \\
II & 17 & 40 \\
III & 8 & 19 \\
IV & 9 & 21 \\
Lateralisation & & $72^{* *}$ \\
Left adrenal & 31 & 28 \\
Right adrenal & 12 & \\
\hline
\end{tabular}

$* * p=0.046$ assuming equal distribution

${ }^{\mathrm{a}}$ For one patient, size and stage at presentation are not known

Surgery was significantly more common in ENSAT stage I-II compared to III-IV (25/25 (100\%) vs. $12 / 17$ (71\%), respectively, $p=0.007$ ), and open surgery (laparotomy or conversion) more common than laparoscopic surgery in ENSAT III-IV compared to I-II $(p=0.002)$. Median tumour size was smaller in the laparoscopic compared to the open surgery group (Table 3, $p<0.0001$ ). Rupture of tumour capsule occurred in four surgeries, and was unrelated to the surgical method $(p=1.0)$.

There was no surgical mortality, but seven (16\%) patients had postoperative complications, graded according to Clavien-Dindo [26] (Table 3). Infections were most common (sepsis $(n=2)$, abscess $(n=2)$, pneumonia $(n=2)$, wound infection $(n=2)$, infection of uncertain origin $(n=1)$ ). Injury of diaphragm caused herniation of the gastric fundus in one patient, requiring surgical correction. The incidence of complications was unrelated to the surgical method (open surgery vs. laparoscopy, $p=0.11$ ). Median hospital stay was significantly longer in the open compared to laparoscopic surgery group (median $8 \mathrm{com}$ pared to 4 days, respectively; $p<0.0001$ ).

\section{Surgery in metastatic disease}

Metastases were resected in four patients (lung metastases, lung metastases followed by three additional resections of lung metastases, lung metastases followed by resection of liver metastases, resection of lymph node metastasis). Two of these patients have achieved sustained remission of $>5$ years, and another patient is alive with $>10$ years survival and unremarkable CT in November 2018. 
Table 3 Surgical features and outcomes

\begin{tabular}{|c|c|c|c|c|c|}
\hline & $\begin{array}{l}\text { All adult } \\
\text { patients } \\
(n=43)\end{array}$ & $\begin{array}{l}\text { Converted }(n=3) \\
\text { adrenalectomies }\end{array}$ & $\begin{array}{l}\text { Open }(n=20)^{\mathrm{a}} \text { and } \\
\text { converted }(n=3)^{\mathrm{b}} \\
\text { adrenalectomies }(n=23)\end{array}$ & $\begin{array}{l}\text { Laparoscopic } \\
\text { adrenalectomies }(n=16)^{\mathrm{c}}\end{array}$ & $\begin{array}{l}p \text {-value (comparisor } \\
\text { between } \\
\text { laparoscopic and } \\
\text { open surgery) }\end{array}$ \\
\hline \multicolumn{6}{|l|}{ Patient characteristics } \\
\hline Age & $61(18-84)$ & $63(63-83)$ & $63(18-84)$ & $55.5(20-69)$ & 0.039 \\
\hline Female sex & $25(58 \%)$ & $2(67 \%)$ & $13(52 \%)$ & $11(69 \%)$ & 0.51 \\
\hline \multicolumn{6}{|c|}{ Tumour characteristics } \\
\hline Axial size (mm) & $91.5(20-196)$ & $74(69-76)$ & $122(69-196)$ & $44(20-96)$ & $<0.0001$ \\
\hline$<60 \mathrm{~mm}$ & $12(29 \%)$ & $0(0 \%)$ & $0(0 \%)$ & $11(73 \%)$ & \\
\hline $60-100 \mathrm{~mm}$ & $11(26 \%)$ & $3(100 \%)$ & $6(26 \%)$ & $4(27 \%)$ & \\
\hline$>100 \mathrm{~mm}$ & $19(45 \%)$ & $0(0 \%)$ & $17(74 \%)$ & $0(0 \%)$ & \\
\hline ENSAT stage & & & & & $0.002^{\mathrm{d}}$ \\
\hline I & $8(19 \%)$ & $0(0 \%)$ & $0(0 \%)$ & $8(53 \%)$ & \\
\hline II & $17(40 \%)$ & $2(67 \%)$ & $12(52 \%)$ & $5(33 \%)$ & \\
\hline III & $8(19 \%)$ & $1(33 \%)$ & $5(22 \%)$ & $1(6 \%)$ & \\
\hline IV & $9(21 \%)$ & $0(0 \%)$ & $6(26 \%)$ & $1(6 \%)$ & \\
\hline \multicolumn{6}{|l|}{ Lateralisation } \\
\hline Left & $31(72 \%)$ & $3(100 \%)$ & $18(78 \%)$ & $10(63 \%)$ & 0.47 \\
\hline Right & $12(28 \%)$ & $0(0 \%)$ & $5(22 \%)$ & $6(37 \%)$ & \\
\hline Complications $\mathrm{s}^{\mathrm{e}}$ & 9 & $1(33 \%)$ & $8(35 \%)$ & $1(6 \%)$ & 0.11 \\
\hline Grade I & 2 & $1(33 \%)$ & $2(9 \%)$ & $0(0 \%)$ & \\
\hline Grade II & 3 & $0(0 \%)$ & $3(13 \%)$ & $0(0 \%)$ & \\
\hline Grade III & 3 & $0(0 \%)$ & $2(9 \%)$ & $1(6 \%)$ & \\
\hline Grade IV & 1 & $0(0 \%)$ & $1(4 \%)$ & $0(0 \%)$ & \\
\hline $\begin{array}{l}\text { Rupture of tumour } \\
\text { capsule }\end{array}$ & 4 & $0(0 \%)$ & $3(13 \%)$ & $1(6 \%)$ & 1.0 \\
\hline $\begin{array}{l}\text { Length of } \\
\text { hospitalisation }\end{array}$ & $6(3-38)$ & $8(6-9)$ & $8(5-38)$ & $4(3-7)$ & $<0.0001$ \\
\hline Follow-up (days) & $\begin{array}{l}1325 \\
(22-7638)\end{array}$ & $260(36-961)$ & $1082(22-5530)$ & $1492.5(576-7638)$ & 0.23 \\
\hline
\end{tabular}

Comparison of open and laparoscopic surgery subgroups

Characteristics of the 39 patients who underwent surgery, including one patient that was inoperable adespite surgical attempts

${ }^{b}$ Cause of conversion: $(6 \mathrm{~cm}$ and $9 \mathrm{~cm})$; view obstructed by tumour, $(8 \mathrm{~cm})$; tumour adherent to pancreas. Continuous variables are presented as medians and range

${ }^{c}$ For a single patient, tumour size and ENSAT stage is not known

${ }^{\mathrm{d}}$ Comparing ENSAT I-II to ENSAT III-IV

${ }^{\mathrm{e}}$ Graded according to Clavien-Dindo classification of surgical complications [26]

\section{Histopathology}

Median Weiss score did not differ between men and women (6.0 (IQR 5.0-8.0) vs. 7.0 (IQR 6.0-9.0), respectively; $p=$ $0.24)$, neither did Helsinki score (20.0, IQR 10.3-31.8 vs. 28, IQR $15.0-36.5, p=0.42)$ or $\mathrm{Ki}-67(11.0 \%$, IQR 5.5-23.8 vs. $20 \%$, IQR $10.0-30.0, p=0.22)$,.

\section{Systemic treatments}

Data on systemic treatments is given in Table 4. Thirty-four (79\%) patients received adjuvant mitotane therapy. Twentytwo of them belonged to ENSAT stage I-II and 11 to III-IV. All except one fulfilled the indications for mitotane treatment as suggested by Fassnacht et al. [27]. Administration of mitotane therapy was not related to ENSAT stage $(p=0.12)$. Target concentrations were reached in $18(60 \%)$ patients in 250 days (78-1055) with a cumulative dose of $870 \mathrm{~g}$ (169-2334). Median duration of mitotane therapy was 896 days (37-2786). Side-effects were common (Table 5) and treatment was discontinued in $11(32 \%)$ patients
Table 4 Treatment modalities used for ACC

\begin{tabular}{lll}
\hline Treatment modality & $n$ & $\%$ \\
\hline Surgical resection alone & 6 & 14 \\
Surgical resection and mitotane & 24 & 56 \\
Surgical resection, mitotane and other systemic treatment & 8 & 19 \\
Mitotane and other systemic treatment & 2 & 5 \\
Systemic treatment other than mitotane & 2 & 5 \\
Only palliative treatment & 1 & 2 \\
\hline
\end{tabular}

because of liver toxicity, gastrointestinal and neurocognitive side-effects (Table 5).

Ten patients received other systemic treatments, including etoposide-doxorubicin-cisplatin (EDP), carboplatin and streptozocin. Two patients achived complete response with sustained remission of $>5$ years (one (ENSAT II) treated with mitotane and carboplatin, and one (ENSAT III) with mitotane and EDP combination therapy). Five patients received palliative radioherapy for metastases. 
Table 5 Mitotane-associated adverse effects and reasons for discontinuation

\begin{tabular}{|c|c|c|c|}
\hline Adverse effects & $\begin{array}{l}n \text { (proportion } \\
\text { of users) }\end{array}$ & $\begin{array}{l}\text { Reasons for } \\
\text { discontinuing } \\
\text { mitotane }\end{array}$ & $n$ \\
\hline Any adverse effect & $31(91 \%)$ & Any reason & 11 \\
\hline $\begin{array}{l}\text { Any gastrointestinal } \\
\text { symptom }\end{array}$ & $21(62 \%)$ & $\begin{array}{l}\text { Increased liver } \\
\text { enzymes }\end{array}$ & 3 \\
\hline Nausea & $13(38 \%)$ & $\begin{array}{l}\text { Nausea and } \\
\text { neurocognitive } \\
\text { symptoms }\end{array}$ & 3 \\
\hline Diarrhoea & $7(21 \%)$ & Diarrhoea & 2 \\
\hline Loss of appetite & $5(15 \%)$ & Abdominal pain & 1 \\
\hline Abdominal pain & $1(3 \%)$ & Back pain & 1 \\
\hline Tiredness/fatigue & $5(15 \%)$ & Leukopenia & 1 \\
\hline Vertigo & $6(18 \%)$ & & \\
\hline $\begin{array}{l}\text { Neurocognitive } \\
\text { symptoms }\end{array}$ & $7(21 \%)$ & & \\
\hline
\end{tabular}

\section{Survival}

Five-year overall survival was $67 \%$ and, for ENSAT I, II, III and IV 100\%, 93\%, 60\% and 11\% respectively. The difference between ENSAT I-II vs. III-IV was $96 \%$ vs. $26 \%$, respectively $(p<0.0001$; Fig. 2$)$. Median follow-up was 35 months, 14/43 (33\%) patients died during follow-up (0/8 stage I, 3/17 (18\%) stage II, 3/8 (38\%) stage III and 8/9 (89\%) stage IV). Risk of death was higher in ENSAT stage III-IV compared to I-II (hazard ratio 9.29, 95\% CI 2.56-33.66) $(p=0.001)$. A Ki-67 $>19 \%$ associated with poorer survival (hazard ratio 4.4; 95\% CI 1.3-14.3) $(p=0.02)$. Helsinki score ( $\leq 17$ vs. $>17)$ did not predict survival $(p=0.22$ ), neither did age ( $\leq 55$ vs. $>55$ years; $p$ $=0.96)$. Symptomatic or incidentally discovered disease ( $p$ $=0.43)$, tumour size $(p=0.15)$, hormonal hypersecretion $(p=0.54)$ or gender $(p=0.14)$ did not predict survival. Open surgery tended to associate with poorer survival than laparoscopic surgery (hazard ratio 4.34, 95\% CI 0.94-20.12) $(p=0.06)$, this tendency disappeared after adjustment for ENSAT stage. Those who did not receive mitotane had poorer survival compared to those who did (hazard ratio 5.24, 95\% CI 1.42-19.38) $(p=0.01)$.

\section{Discussion}

We report on a modern series of ACC, including all patients diagnosed at a single centre in years 2002-2018 and demonstrate that almost $80 \%$ nowadays present as asymptomatic incidentally discovered adrenal masses, and that on nonenhanced CT, HU was $>20$ for all cases. This is in contrast to the literature, reporting incidental tumour finding

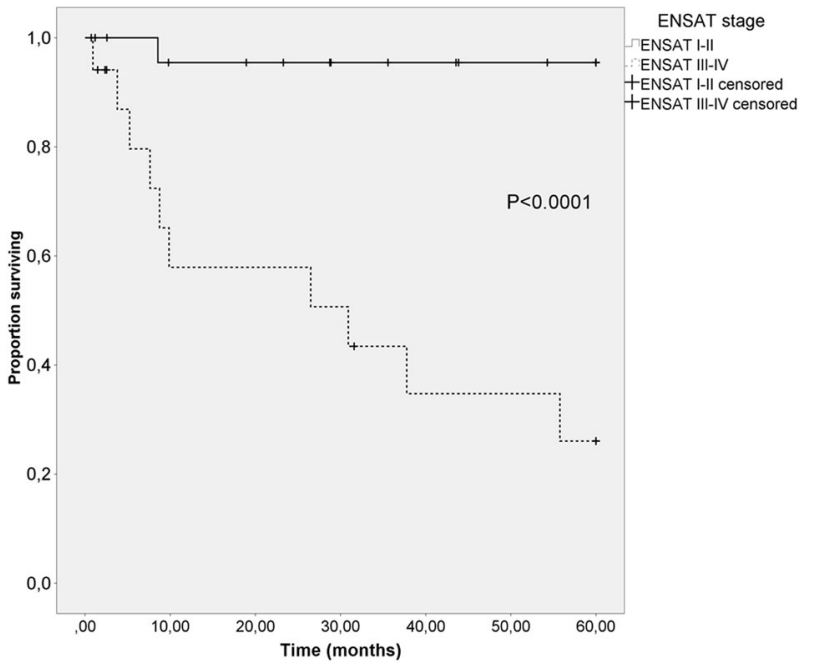

Fig. 2 Comparison of overall survival rates of ENSAT stage I-II and III-IV patients using Kaplan-Meier method

in $10-15 \%$ of ACC, probably reflecting historical cases diagnosed in 1970-1990 [2, 20, 21]. Adrenal incidentalomas are common due to frequent imaging, the majority representing nonfunctioning adrenal adenomas for which neither surgery nor further imaging is needed [22]. Most adrenal adenomas are homogenous, $<4 \mathrm{~cm}$ large and lipid rich, and thus characterised by $<10 \mathrm{HU}$ on nonenhanced CT $[22,28]$. ACC and pheochromocytoma are the most important differential diagnoses and must be adequately diagnosed. A German study concluded that $\mathrm{HU}>21$ provides the best accuracy for diagnosing ACC (96\% sensitivity, $80 \%$ specificity), however, Weiss scores were not reported [29]. Radiological features of early, small ACCs are rarely reported in the literature [30] and may easily be overlooked. The smallest ACCs of 2 and $2.5 \mathrm{~cm}$ in the present study were incidental findings on chest and trauma CT (a 59-year old woman, a 22-year old male), with noncontrast HUs of 34 and 40, and Weiss scores of 7 and 4, respectively. Ozsari et al. [31] reported substantial diagnostic delay of up to 89 months in ACC, in a series of patients with incidentally found adrenal tumours characterised by a high noncontrast $\mathrm{HU}$ and small $(<4 \mathrm{~cm})$ tumour size. The authors concluded that presumed benign nature of pre-existing masses based on size is the main reason for delayed ACC diagnosis.

Data on the incidence of ACC is scarce. We assessed nationwide incidence in 2001-2015 and it is close to the previously reported 1 per million persons annually. A Dutch study reported a declining incidence trend [1], while a recent report from the SEER database, U.S.A, reported increasing trends (597 cases in 1995-2004 compared to 933 cases in 2005-2014) [32].

Open surgery is considered the standard approach for large tumours with high suspicion of or confirmed ACC, at 
least for tumours demonstrating local invasion. The recent ESE Clinical Practice Guidelines on ACC [33] suggest laparoscopic surgery for tumours $<6 \mathrm{~cm}$ without evidence of invasion. In the present study, four adult patients with tumour diameter $6-10 \mathrm{~cm}$, not characterised by invasion successfully underwent laparoscopic surgery. Our results indicate that laparoscopic surgery can be applied in selected cases also for tumours $>6 \mathrm{~cm}$. Importantly, laparoscopic surgery enabled significantly shorter hospitalisation compared to open surgery, and did not impair survival. Two cases were converted because the tumour obstructed the view and one because of adherence to the pancreas. Surgery for ACC, especially laparoscopic, must be reserved for high-volume centres [34, 35]. In 2016 and 2017, the number of laparoscopic adrenalectomies performed at the Helsinki University Hospital was 39 and 51, respectively. In advanced ACC, survival is still very poor, and metastatic ACC is characterised by higher mutation rate and tumour heterogeneity than the primary tumours [36]. As medical treatment options are limited, surgery of metastases should be considered in selected cases. In the present study, four patients underwent resection of metastases, and three clearly benefited, two (ENSAT I and IV; lung metastases, lung metastasis followed by liver metastasis) are in remission (survival $>6$ and $>9$ years), the third patient (ENSAT II; recurring lung metastases) is alive with prolonged survival of $>10$ years.

Of ten patients undergoing further systemic therapy, one treated with mitotane and carboplatin and one with mitotane and EDP (combination therapy, ENSAT stage II and III, respectively) achieved complete response and are alive ( $>$ 5 years).

In the present cohort, 5-year survival rates were 100\%, 93\%, 60\% for ENSAT I, II and III, respectively. This compares favourably to older cohorts $[10,37-40]$ and probably reflects the high percentage of patients undergoing surgery (88\%) and mitotane therapy (79\%). However, for ENSAT stage IV, 5-year survival remains poor (11\%). ENSAT stage and Ki67>19\% predicted survival and, as previously reported, mitotane therapy was associated with better survival [7, 33]. Berruti et al. [41] demonstrated that overt clinical hypercortisolism was a negative prognostic factor in ACC. In the present study, $41 \%$ had biochemically verified hypercortisolism and this did not predict outcome. The study by Berruti et al. was much larger than the present one, in addition, hypercortisolism was defined differently. Currently, the impact of cortisol secretion on survival in ACC remains uncertain [2].

Mitotane frequently causes side-effects and these were quite common $(91 \%)$ also in the present study. Mitotane therapy associates with better survival, it is thus important to tailor the treatment according to best practice, including drug concentration monitoring and adequate replacement with rather high hydrocortisone doses, as well as thyroxine and testosterone [42].

As ACC is a very rare cancer, the sample size of the present study was small and this is a clear limitation. Larger series are needed to confirm some of the findings of the present study, such as percentage of cases presenting as incidental cases in other modern series, better characteristics of small ACCs, the role of laparoscopic surgery and surgery of metastases. It is unclear why most of the ACCs were found in the left and not the right adrenal.

In conclusion, contemporary ACC predominantly presents as an incidental imaging finding, characterised by $\mathrm{HU}$ $>20$ on nonenhanced $\mathrm{CT}$ but variable tumour size (20-196 mm). Malignancy cannot be ruled out by small tumour size only. The 5-year survival of $96 \%$ in ENSAT stage I-III compares favourably to previous studies.

Acknowledgements We thank endocrine nurse Marketta Halinen for excellent technical assistance and Prof. Timo Sane for critically reviewing the manuscript.

Funding Open access funding provided by University of Helsinki including Helsinki University Central Hospital. This study was funded by the Helsinki University Hospital Research Funds (TYH2016129 and TYH2017138 to C. Schalin-Jäntti) and Finska Läkaresällskapet (to C. Schalin-Jäntti and C. Haglund).

\section{Compliance with ethical standards}

Conflict of interest The authors declare that they have no conflict of interest.

Informed consent Authorisation to perform this retrospective study without individual consent was granted by the Scientific Board of the Abdominal Centre, Helsinki University Hospital (HUS §45, 269/ 2017).

Publisher's note: Springer Nature remains neutral with regard to jurisdictional claims in published maps and institutional affiliations.

Open Access This article is distributed under the terms of the Creative Commons Attribution 4.0 International License (http://crea tivecommons.org/licenses/by/4.0/), which permits unrestricted use, distribution, and reproduction in any medium, provided you give appropriate credit to the original author(s) and the source, provide a link to the Creative Commons license, and indicate if changes were made.

\section{References}

1. T.M. Kerkhofs, R.H. Verhoeven, J.M. Van der Zwan, J. Dieleman, M.N. Kerstens, T.P. Links, L.V. Van de Poll-Franse, H.R. Haak, Adrenocortical carcinoma: a population-based study on incidence and survival in the Netherlands since 1993. Eur. J. Cancer 49, 2579-2586 (2013). https://doi.org/10.1016/j.ejca.2013. 02.034 .

2. A. Jouinot, J. Bertherat, Management of Endocrine Disease Adrenocortical carcinoma: differentiating the good from the poor 
prognosis tumors. Eur. J. Endocrinol. 178, R215-R230 (2018). https://doi.org/10.1530/EJE-18-0027

3. M. Fassnacht, S. Johanssen, M. Quinkler, P. Bucsky, H.S. Willenberg, F. Beuschlein, M. Terzolo, H.H. Mueller, S. Hahner, B. Allolio; German Adrenocortical Carcinoma Registry Group, European Network for the Study of Adrenal Tumors, Limited prognostic value of the 2004 International Union Against Cancer staging classification for adrenocortical carcinoma: proposal for a Revised TNM Classification. Cancer 115, 243-250 (2009). https:// doi.org/10.1002/cncr.24030.

4. G. Assie, G. Antoni, F. Tissier, B. Caillou, G. Abiven, C. Gicquel, S. Leboulleux, J.P. Travagli, C. Dromain, X. Bertagna, J. Bertherat, M. Schlumberger, E. Baudin, Prognostic parameters of metastatic adrenocortical carcinoma. J. Clin. Endocrinol. Metab. 92, 148-154 (2007).

5. E. Kebebew, E. Reiff, Q.Y. Duh, O.H. Clark, A. McMillan, Extent of disease at presentation and outcome for adrenocortical carcinoma: have we made progress? World J. Surg. 30, 872-878 (2006). https://doi.org/10.1007/s00268-005-0329-x.

6. K.Y. Bilimoria, W.T. Shen, D. Elaraj, D.J. Bentrem, D.J. Winchester, E. Kebebew, C. Sturgeon, Adrenocortical carcinoma in the United States: treatment utilization and prognostic factors. Cancer 113, 3130-3136 (2008). https://doi.org/10.1002/cncr.23886.

7. T. Else, A.R. Williams, A. Sabolch, S. Jolly, B.S. Miller, G.D. Hammer, Adjuvant therapies and patient and tumor characteristics associated with survival of adult patients with adrenocortical carcinoma. J. Clin. Endocrinol. Metab. 99, 455-461 (2014). https://doi.org/10.1210/jc.2013-2856.

8. T. Else, A.C. Kim, A. Sabolch, V.M. Raymond, A. Kandathil, E. M. Caoili, S. Jolly, B.S. Miller, T.J. Giordano, G.D. Hammer, Adrenocortical carcinoma. Endocr. Rev. 35, 282-326 (2014). https://doi.org/10.1210/er.2013-1029.

9. M. Ayala-Ramirez, S. Jasim, L. Feng, S. Ejaz, F. Deniz, N. Busaidy, S.G. Waguespack, A. Naing, K. Sircar, C.G. Wood, L. Pagliaro, C. Jimenez, R. Vassilopoulou-Sellin, M.A. Habra, Adrenocortical carcinoma: clinical outcomes and prognosis of 330 patients at a tertiary care center. Eur. J. Endocrinol. 169, 891-899 (2013). https://doi.org/10.1530/EJE-13-0519.

10. P. Icard, P. Goudet, C. Charpenay, B. Andreassian, B. Carnaille, Y. Chapuis, P. Cougard, J.F. Henry, C. Proye, Adrenocortical carcinomas: surgical trends and results of a 253-patient series from the French Association of Endocrine Surgeons study group. World J. Surg. 25, 891-897 (2001)

11. S. Wang, S.S. Chen, W.C. Gao, L. Bai, L. Luo, X.G. Zheng, Y. Luo, Prognostic factors of adrenocortical carcinoma: An analysis of the surveillance epidemiology and end results (SEER) Database. Asian Pac. J. Cancer. Prev. 18, 2817-2823 (2017). https:// doi.org/10.22034/APJCP.2017.18.10.2817.

12. E. Michalkiewicz, R. Sandrini, B. Figueiredo, E.C. Miranda, E. Caran, A.G. Oliveira-Filho, R. Marques, M.A. Pianovski, L. Lacerda, L.M. Cristofani, J. Jenkins, C. Rodriguez-Galindo, R.C. Ribeiro, Clinical and outcome characteristics of children with adrenocortical tumors: a report from the International Pediatric Adrenocortical Tumor Registry. J. Clin. Oncol. 22, 838-845 (2004). https://doi.org/10.1200/JCO.2004.08.085.

13. M. Pennanen, I. Heiskanen, T. Sane, S. Remes, H. Mustonen, C. Haglund, J. Arola, Helsinki score-a novel model for prediction of metastases in adrenocortical carcinomas. Hum. Pathol. 46, 404-410 (2015). https://doi.org/10.1016/j.humpath.2014.11.015.

14. F. Beuschlein, J. Weigel, W. Saeger, M. Kroiss, V. Wild, F. Daffara, R. Libe, A. Ardito, A. Al Ghuzlan, M. Quinkler, A. Osswald, C.L. Ronchi, R. de Krijger, R.A. Feelders, J. Waldmann, H.S. Willenberg, T. Deutschbein, A. Stell, M. Reincke, M. Papotti, E. Baudin, F. Tissier, H.R. Haak, P. Loli, M. Terzolo, B. Allolio, H.H. Muller, M. Fassnacht, Major prognostic role of Ki67 in localized adrenocortical carcinoma after complete resection. J.
Clin. Endocrinol. Metab. 100, 841-849 (2015). https://doi.org/10. 1210/jc.2014-3182.

15. T.B. Tran, L.M. Postlewait, S.K. Maithel, J.D. Prescott, T.S. Wang, J. Glenn, J.E. Phay, K. Keplinger, R.C. Fields, L.X. Jin, S. M. Weber, A. Salem, J.K. Sicklick, S. Gad, A.C. Yopp, J.C. Mansour, Q.Y. Duh, N. Seiser, C.C. Solorzano, C.M. Kiernan, K. I. Votanopoulos, E.A. Levine, I. Hatzaras, R. Shenoy, T.M. Pawlik, J.A. Norton, G.A. Poultsides, Actual 10-year survivors following resection of adrenocortical carcinoma. J. Surg. Oncol. 114, 971-976 (2016). https://doi.org/10.1002/jso.24439.

16. M. Terzolo, A. Angeli, M. Fassnacht, F. Daffara, L. Tauchmanova, P.A. Conton, R. Rossetto, L. Buci, P. Sperone, E. Grossrubatscher, G. Reimondo, E. Bollito, M. Papotti, W. Saeger, S. Hahner, A.C. Koschker, E. Arvat, B. Ambrosi, P. Loli, G. Lombardi, M. Mannelli, P. Bruzzi, F. Mantero, B. Allolio, L. Dogliotti, A. Berruti, Adjuvant mitotane treatment for adrenocortical carcinoma. N. Engl. J. Med. 356, 2372-2380 (2007).

17. A. Berruti, S. Grisanti, A. Pulzer, M. Claps, F. Daffara, P. Loli, M. Mannelli, M. Boscaro, E. Arvat, G. Tiberio, S. Hahner, B. Zaggia, F. Porpiglia, M. Volante, M. Fassnacht, M. Terzolo, Long-term outcomes of adjuvant mitotane therapy in patients with radically resected adrenocortical carcinoma. J. Clin. Endocrinol. Metab. 102, 1358-1365 (2017). https://doi.org/10.1210/jc.2016-2894.

18. M. Fassnacht, M. Terzolo, B. Allolio, E. Baudin, H. Haak, A. Berruti, S. Welin, C. Schade-Brittinger, A. Lacroix, B. Jarzab, H. Sorbye, D.J. Torpy, V. Stepan, D.E. Schteingart, W. Arlt, M. Kroiss, S. Leboulleux, P. Sperone, A. Sundin, I. Hermsen, S. Hahner, H.S. Willenberg, A. Tabarin, M. Quinkler, C. de la Fouchardiere, M. Schlumberger, F. Mantero, D. Weismann, F. Beuschlein, H. Gelderblom, H. Wilmink, M. Sender, M. Edgerly, W. Kenn, T. Fojo, H.H. Muller, B. Skogseid; FIRM-ACT Study Group, Combination chemotherapy in advanced adrenocortical carcinoma. N. Engl. J. Med. 366, 2189-2197 (2012). https://doi. org/10.1056/NEJMoa1200966.

19. F. Megerle, W. Herrmann, W. Schloetelburg, C.L. Ronchi, A. Pulzer, M. Quinkler, F. Beuschlein, S. Hahner, M. Kroiss, M. Fassnacht; German ACC Study Group, Mitotane monotherapy in patients with advanced adrenocortical carcinoma. J. Clin. Endocrinol. Metab. 103, 1686-1695 (2018). https://doi.org/10.1210/jc. 2017-02591.

20. A.P. Dackiw, J.E. Lee, R.F. Gagel, D.B. Evans, Adrenal cortical carcinoma. World J. Surg. 25, 914-926 (2001)

21. S. Johanssen, S. Hahner, W. Saeger, M. Quinkler, F. Beuschlein, H. Dralle, M. Haaf, M. Kroiss, C. Jurowich, P. Langer, W. Oelkers, M. Spahn, H.S. Willenberg, U. Mader, B. Allolio, M. Fassnacht, Deficits in the management of patients with adrenocortical carcinoma in Germany. Dtsch. Arztebl Int. 107, 885-891 (2010). https://doi.org/10.3238/arztebl.2010.0885.

22. M. Fassnacht, W. Arlt, I. Bancos, H. Dralle, J. Newell-Price, A. Sahdev, A. Tabarin, M. Terzolo, S. Tsagarakis, O.M. Dekkers, Management of adrenal incidentalomas: European Society of Endocrinology Clinical Practice Guideline in collaboration with the European Network for the Study of Adrenal Tumors. Eur. J. Endocrinol. 175, G1-G34 (2016). https://doi.org/10.1530/EJE-160467.

23. T. Sane, C. Schalin-Jantti, M. Raade, Is biochemical screening for pheochromocytoma in adrenal incidentalomas expressing low unenhanced attenuation on computed tomography necessary? J. Clin. Endocrinol. Metab. 97, 2077-2083 (2012). https://doi.org/ 10.1210/jc.2012-1061.

24. L.M. Weiss, L.J. Medeiros, A.L. Vickery, Jr., Pathologic features of prognostic significance in adrenocortical carcinoma. Am. J. Surg. Pathol. 13, 202-206 (1989).

25. L.M. Weiss, Comparative histologic study of 43 metastasizing and nonmetastasizing adrenocortical tumors. Am. J. Surg. Pathol. 8, 163-169 (1984) 
26. D. Dindo, N. Demartines, P.A. Clavien, Classification of surgical complications: a new proposal with evaluation in a cohort of 6336 patients and results of a survey. Ann. Surg. 240, 205-213 (2004).

27. M. Fassnacht, B. Allolio, Clinical management of adrenocortical carcinoma. Best Pract. Res. Clin. Endocrinol. Metab. 23, 273-289 (2009). https://doi.org/10.1016/j.beem.2008.10.008.

28. C. Schalin-Jantti, M. Raade, E. Hamalainen, T. Sane, A 5-year prospective follow-up study of lipid-rich adrenal incidentalomas: No tumor growth or development of hormonal hypersecretion. Endocrinol. Metab. (Seoul) 30, 481-487 (2015). https://doi.org/ 10.3803/EnM.2015.30.4.481.

29. S. Petersenn, P.A. Richter, T. Broemel, C.O. Ritter, T. Deutschbein, F.U. Beil, B. Allolio, M. Fassnacht; German ACC Study Group, Computed tomography criteria for discrimination of adrenal adenomas and adrenocortical carcinomas: analysis of the German ACC registry. Eur. J. Endocrinol. 172, 415-422 (2015). https://doi.org/10.1530/EJE-14-0916.

30. C.C. Barnett Jr., D.G. Varma, A.K. El-Naggar, A.P. Dackiw, G.A. Porter, A.S. Pearson, A.P. Kudelka, R.F. Gagel, D.B. Evans, J.E. Lee, Limitations of size as a criterion in the evaluation of adrenal tumors. Surgery 128, 973-82 (2000).

31. L. Ozsari, M. Kutahyalioglu, K.M. Elsayes, R.A. Vicens, K. Sircar, T. Jazaerly, S.G. Waguespack, N.L. Busaidy, M.E. Cabanillas, R. Dadu, M.I. Hu, R. Vassilopoulou-Sellin, C. Jimenez, J.E. Lee, M.A. Habra, Preexisting adrenal masses in patients with adrenocortical carcinoma: clinical and radiological factors contributing to delayed diagnosis. Endocrine 51, 351-359 (2016). https://doi.org/10.1007/s12020-015-0694-7.

32. E. Sharma, S. Dahal, P. Sharma, A. Bhandari, V. Gupta, B. Amgai, S. Dahal, The characteristics and trends in adrenocortical carcinoma: A United States population based study. J. Clin. Med. Res. 10, 636-640 (2018). https://doi.org/10.14740/jocmr3503w.

33. M. Fassnacht, O. Dekkers, T. Else, E. Baudin, A. Berruti, R.R. de Krijger, H.R. Haak, R. Mihai, G. Assie, M. Terzolo, European Society of Endocrinology Clinical Practice Guidelines on the Management of Adrenocortical Carcinoma in Adults, in collaboration with the European Network for the Study of Adrenal Tumors. Eur. J. Endocrinol. 179, G1-G46 (2018). EJE_18-0608.

34. M. Barczynski, A. Konturek, F. Golkowski, S. Cichon, B. Huszno, K. Peitgen, M.K. Walz, Posterior retroperitoneoscopic adrenalectomy: a comparison between the initial experience in the invention phase and introductory phase of the new surgical technique. World J. Surg. 31, 65-71 (2007). https://doi.org/10. 1007/s00268-006-0083-8.
35. J.M. Schreinemakers, G.J. Kiela, G.D. Valk, M.R. Vriens, I.H. Rinkes, Retroperitoneal endoscopic adrenalectomy is safe and effective. Br. J. Surg. 97, 1667-1672 (2010). https://doi.org/10. 1002/bjs.7191.

36. S.K. Gara, J. Lack, L. Zhang, E. Harris, M. Cam, E. Kebebew, Metastatic adrenocortical carcinoma displays higher mutation rate and tumor heterogeneity than primary tumors. Nat. Commun. $\mathbf{9}$, 4172-018-06366-z (2018). https://doi.org/10.1038/s41467-01806366-z.

37. E.A. Asare, T.S. Wang, D.P. Winchester, K. Mallin, E. Kebebew, C. Sturgeon, A novel staging system for adrenocortical carcinoma better predicts survival in patients with stage I/II disease. Surgery 156, 1378-85 (2014). https://doi.org/10.1016/j.surg.2014.08.018.

38. T.M. Kerkhofs, M.H. Ettaieb, I.G. Hermsen, H.R. Haak, Developing treatment for adrenocortical carcinoma. Endocr. Relat. Cancer 22 R325-38 (2015). https://doi.org/10.1530/ERC-15-0318.

39. R. Libe, I. Borget, C.L. Ronchi, B. Zaggia, M. Kroiss, T. Kerkhofs, J. Bertherat, M. Volante, M. Quinkler, O. Chabre, M. Bala, A. Tabarin, F. Beuschlein, D. Vezzosi, T. Deutschbein, F. Borson-Chazot, I. Hermsen, A. Stell, C. Fottner, S. Leboulleux, S. Hahner, M. Mannelli, A. Berruti, H. Haak, M. Terzolo, M. Fassnacht, E. Baudin, ENSAT network Prognostic factors in stage III-IV adrenocortical carcinomas (ACC): an European Network for the Study of Adrenal Tumor (ENSAT) study. Ann. Oncol. 26, 2119-2125 (2015). https://doi.org/10.1093/annonc/ mdv329

40. M. Fassnacht, S. Johanssen, W. Fenske, D. Weismann, A. Agha, F. Beuschlein, D. Fuhrer, C. Jurowich, M. Quinkler, S. Petersenn, M. Spahn, S. Hahner, B. Allolio; German ACC Registry Group, Improved survival in patients with stage II adrenocortical carcinoma followed up prospectively by specialized centers. J. Clin. Endocrinol. Metab. 95, 4925-4932 (2010). https://doi.org/10. 1210/jc.2010-0803.

41. A. Berruti, M. Fassnacht, H. Haak, T. Else, E. Baudin, P. Sperone, M. Kroiss, T. Kerkhofs, A.R. Williams, A. Ardito, S. Leboulleux, M. Volante, T. Deutschbein, R. Feelders, C. Ronchi, S. Grisanti, H. Gelderblom, F. Porpiglia, M. Papotti, G.D. Hammer, B. Allolio, M. Terzolo, Prognostic role of overt hypercortisolism in completely operated patients with adrenocortical cancer. Eur. Urol. 65, 832-838 (2014). https://doi.org/10.1016/j.eururo.2013. 11.006 .

42. M. Terzolo, A. Ardito, B. Zaggia, F. Laino, A. Germano, S. De Francia, F. Daffara, A. Berruti, Management of adjuvant mitotane therapy following resection of adrenal cancer. Endocrine 42, 521-525 (2012). https://doi.org/10.1007/s12020-012-9719-7. 